\title{
Simüle Hasta Kullanımına İlişkin Öğrenci Görüşleri
}

\section{The Views Of Students Regarding The Use Of Simulated Patient}

\author{
Mevlüde Karadağ ${ }^{1}$, Nurcan Çalışkan ${ }^{1}$, Özge İşeri ${ }^{2}$
}

${ }^{1}$ Gazi Üniversitesi, Sağlık Bilimleri Fakültesi, Hemşirelik Bölümü.

${ }^{2}$ Gaziosmanpaşa Üniversitesi, Tokat Sağlık Yüksekokulu Hemşirelik

\section{Corresponding Author:}

Dr. Mevlüde Karadağ

\section{Address:}

Gazi Üniversitesi, Sağlik Bilimleri Fakültesi, Hemşirelik Bölümü.

\section{E-mail:}

mevludekaradag@gmail.com

\section{Başvuru Tarihi/Received :}

27-10-2013

Kabul Tarihi/Accepted:

03-12-2013

\section{ÖZET}

Amaç: Çalıșma, bir hemșirelik programında uygulanan simüle hasta kullanımına ilişkin öğrenci görüşlerinin karşılaştırmalı olarak paylaşılması amacıyla yapılmıştır.

Materyal- metod: Çalışma, Orta Karadeniz Bölgesi'nde bulunan bir Sağlık Yüksekokulu Hemşirelik Bölümü’nde yapılmıştır. Çalışmanın evrenini, 2011-2012 eğitim öğretim yılında ikinci sınıfın bahar döneminde okutulan Cerrahi Hastalıkları Hemşireliği Dersi'ne devam eden 70 öğrenci oluşturmuştur. Bu öğrencilerin, 35'i çalışma, 35'i ise kontrol grubu olarak rastgele atanmıştır. Çalışmada spinal kord travması geçiren bir hasta vakası kullanılmıştır. Çalışma grubu simüle hasta, kontrol grubu ise vaka çalışması yolu ile bireysel hemşirelik bakım planlarını hazırlamışlardır.

Çalışmanın verileri, araştırmacılar tarafindan hazırlanan soru formu ve ögrencilerin hazırladıkları bakım planları ile toplanmıştır. Verilerin analizinde ki-kare ve t testi kullanılmıştır.

Bulgular: Öğrencilerin, eğitim yöntemlerinin öğrenmeye, bakımı ve girişimleri planlamaya katkısını algılama ortalamaları 100 puan üzerinden çalışma grubunda 89.7, kontrol grubunda ise 80.57 olmuştur ve aradaki fark istatistiksel olarak önemlidir $(\mathrm{p}<0.05)$. Simule hastayla çalışan öğrenciler, "Etkili öğrenmeyi sağladığını" ve "Gerçek hastayla çalışma şansı sağladığını” ifade etmişlerdir.

Sonuç: Hemşirelik eğitiminde simüle hastaların kullanımının, öğrencilerin gerçeğe en yakın tıbbi durumları, klinik problemleri değerlendirebilmelerine ve hemşirelik bakımını planlamalarına katkı sağladığı düşünülmektedir.

Anahtar Kelimeler: Simule hasta, öğrenci görüşleri, hemşirelik eğitimi

\section{ABSTRACT}

Purpose: The study was conducted in order to share in comparison the views of students regarding the use of simulated patients administering in the nursing program.

Materials and methods: The study was conducted in the Department of Health Sciences School of Nursing which is located in the Middle Black Sea Region. The study population was formed with 70 students who have been ongoing Surgical Nursing Courses which are thought in the spring semester of second class of the 2011-2012 academic year. Thirty-five of these students were assigned to the study group randomly and 35 of them were assigned to the control group randomly. In the study, a case of patient with spinal cord trauma was used. The individual nursing care plans were prepared by study group via simulated patient study and control group via case study. Data of the study were collected with a questionnaire prepared by the researchers and the care plans prepared by the students. Chi-square and tests were used to analyze the data.

Results: The mean points of the students for the detection of the contribution of training methods on learning, planning of care and interventions were 89.7 out of 100 points in the study group and 80.57 out of 100 points in the control group and the difference was statistically significant $(\mathrm{p}<0.05)$. The students working with the simulated patient expressed that working with the simulated patient "provided an effective learning" and "provided a chance to work with real patients".

Conclusion: It is considered that, the use of simulated patients in nursing education contributes that the students evaluate medical conditions and the clinical problems which are the most close to the reality and the planning of the nursing care.

Keywords: Simulated patient, the views of students, nursing education

\section{GíRiş}


Teknolojik gelişmelere paralel olarak modern tıp ve bakım hizmetleri giderek daha karmaşık hale gelmektedir (1). Hastanede yatış süresinin kısalması, akut hastalıkların sayısının artması, hemşire sayısının azalması, tıbbi hatalarla ilgili farkındalığın ve bu hatalara yönelik endişelerin artması gibi sağlık bakım ortamındaki değişimler, sağlık profesyonellerinin klinik eğitimini güçleştirmektedir (1,2). Ayrıca klinik uygulamalar, hastaya zarar verme korkusu, teorik bilgiyi klinik ortamlara aktarmada zorlanma ve destekleyici ilişkilerin yetersizliği gibi nedenlerden dolayı hemşirelik öğrencileri için daha zor ve sıkıntılı olabilmektedir (3). Yaşanılan bu sorunlara rağmen, hemşire eğitimcilerden sürekli değişen ve daha çok akut klinik problemlerin olduğu ortamlara öğrencileri iyi hazırlamaları beklenmektedir (4). Klinik uygulamalarda yaşanılan bu güçlükleri aşmak için hemşirelik eğitiminde simülasyon kullanımı giderek yaygınlaşmış ve önem kazanmıştır (5). Simülasyon eğitimi, hastaları belli risklere maruz burakmadan beceri eğitimini kolaylaştırmakta, öğrencilerin anksiyete yaşamadan deneyim kazanmasına ve öğrenim için güvenli bir ortam sağlanmasına izin vermektedir (2).

Benzetim olarak da isimlendirilen simülasyon, gerçekte var olan görevlerin, ilişkilerin, ekipmanların, davranışların ya da bazı bilişsel aktivitelerin taklit edilmesi olarak tanımlanmaktadır (6). Hemşirelik eğitiminde kullanılan simülasyon uygulamaları kapsamında; video, DVD gösterimi, bilgisayar temelli simülasyon, bilgisayar kontrollü simülatör, interaktif hasta simülatörleri ve simüle/standardize hastalarla rol oynama yer almaktadır (7). Simüle/standardize hasta, belli bir hastalık konusunda doğru öykü ve muayene bulgularını göstermek amacı ile eğitilmiş aktör veya gerçek hastadır $(8,9)$.
Simüle hasta kullanımı sınıfla klinik arasındaki engeli kaldırarak, öğrencinin gerçek klinik ortama gitmeden önce sinıf ortamında gerçekçi bir klinik öğrenme deneyimini yaşayarak öğrenmesine katkı sağlamaktadır (3). Gözlemlerimize ve deneyimlerimize göre; hemşirelik sürecinin kullanılmasının öğretilmesinde, öğrencilere veriler toplu şekilde verilmekte ve bu verilerden yola çıkılarak hemşirelik bakımının planlaması anlatılmaktadır. $\mathrm{Bu}$ şekilde öğrenci, hastadan sistematik bir şekilde veri toplanma aşamasını hem uygulama laboratuarında hem de klikte görememekte ve hasta-hemşire görüşmesi ile ilgili deneyim kazanmada zorlanabilmektedir. Kinik uygulama esnasında, öğrenci sayısının fazla olması gibi nedenlerle, öğretim elemanının öğrencinin veri toplamak amaciyla hastahemşire görüşmesini izleme ve değerlendirme şans1 da azdır. Öğrenci, hasta görüşmesini genellikle deneme yanılma yoluyla öğrenmektedir. Klinik uygulama deneyimlerimizde de çoğu zaman öğrenci bakım planlarının veri toplama aşamalarının sınırlı kaldığını gözlemledik. Literatürde öğrenci eğitiminde simüle hasta kullanımı ile ilgili yapılmış araştırmalar (2,10-18) mevcuttur. Ancak, lisans eğitiminde simülasyon kullanımı giderek yaygınlaşmakla birlikte, senaryo temelli simüle hasta eğitiminin hemşirelik öğrencilerinde etkinliğini gösteren çalışmalara ihtiyaç vardır $(10,11,12)$. Türkiye'de tıp eğitimde simüle hasta kullanılmaktadır (8) ancak, hemşirelik eğitiminde senaryo temelli simüle hasta kullanımı ile ilgili bir çalışmaya rastlanılamamıştır. Dolayısıyla, bu yenilikçi uygulamaya ilişkin hemşirelik öğrencilerinin görüşlerinin paylaşılmasının önemli olduğunu düşünmekteyiz. 


\section{DOI: $10.16899 /$ ctd. 83205}

Çalışma, bir hemşirelik programında uygulanan simüle hasta kullanımına ilişkin öğrenci görüşlerinin karşılaştırmalı olarak paylaşılması amacıyla yapılmıştır. Çalışmanın evrenini, 2011-2012 eğitim öğretim yılında, Orta Karadeniz Bölgesi'nde bulunan bir Sağlik Yüksekokulu Hemşirelik Bölümü'nde öğrenim gören, ikinci sınıfın bahar döneminde okutulan Cerrahi Hastalıkları Hemşireliği Dersi'ne devam eden 70 öğrenci oluşturmuştur. Çalışmada örneklem seçimine gidilmemiş, evren üzerinde çalışılmıştır.

Simüle hasta kullanımına ilişkin öğrenci görüşlerinin karşılaştırılabilmesi için kontrol grubu kullanılmıştır. Bu amaçla her öğrenciye bir sayı verilerek, rastgele sayllar tablosundan sınıf iki gruba bölünmüştür. $\mathrm{Bu}$ iki grup arasından da kura çekilerek çalışma (n:35) ve kontrol grubu (n:35) belirlenmiştir.

\section{HASTA SENARYOSUNUN VE SIMÜLE HASTANIN EĞITIMIE HAZIRLANMASI}

Öğrencilerin klinik uygulamada spinal kord vakasıyla karşılaşma olanakları sınırlı olduğundan, çalışmada spinal kord travması geçiren bir hasta vakası kullanılmıştır. Vaka, Cerrahi Hastalıkları Hemşireliği Dersi kapsamında daha önceki yıllarda da kullanılan, inşaattan düşme nedeniyle servikal 5-7 dislokasyon tanısı alan, 40 yaşında, erkek hastaya bakım verirken ikinci araştırmacı tarafından hazırlanmış bakım planından kurgulanmıştır. Bakım planından yararlanarak vaka senaryosu birinci araştırmacı tarafından hazırlanmıştır.

Simüle hasta $(\mathrm{SH})$ rolünü oynamada eğitilmiş tiyatro oyuncusu kullanılmıştır. Hazırlanan vaka senaryosu SH rolünü oynayan tiyatro sanatçısına 15 gün öncesinden verilmiştir. Çalışmanın uygulamasının yapılacağı günden bir gün önce, birinci ve üçüncü araştırmacılar ve $\mathrm{SH}$ toplantı yaparak hasta- hemşire görüşmesinin provasını yapmışlardır.

Çalışmanın uygulandığ1 gün, bölümün uygulama laboratuarında bir hasta ünitesi hazırlanmıştır. Pijama giymiş ve yatakta yatan SH'ya boyunluk takılmış, intravenöz sıv1 tedavisi başlanmış ve üriner kateter yerleştirilmiş görüntüsü oluş̧urulmuştur. SH hasta ünitesinde yatan hasta, üçüncü araştırmac1 ise hemşire olarak çalışma grubu öğrencilerini karşılamıştır.

\section{ÇALIŞMANIN UYGULANMASI}

SH grubu olarak isimlendirilen çalışma grubu, rastgele biri 8 , diğerleri 9 kişilik 4 gruba ayrılmıştır. Her grup tek tek ve birbirlerini görmeyecek şekilde uygulama laboratuarına alınmış ve hemşire rolünü canlandıran üçüncü araştırmac1 ve $\mathrm{SH}$ rolünü oynayan tiyatro sanatçısının hasta-hemşire görüşmesini izlemişlerdir. Öğrenciler bu hasta-hemşire görüşmesini izleyerek, vaka verilerine ilişkin bilgileri dinlemişler ve notlar almışlardır. Görüşme, yaklaşık 30 dakika sürmüştür. $\mathrm{Bu}$ hasta-hemşire görüşmesinin canlandırılması dört kez tekrarlanmıştır. Görüşmeyi dinledikten sonra öğrencilerden, sınıfta kendi gruplarıyla grup çalışması yapmaları istenmiştir. Grup çalışmasında, öğrenciler vakaya ilişkin hemşirelik tanılarını ve hemşirelik girişimlerini tartışmışlardır. Grup çalışması yaklaşık bir saat sürmüştür. Grup çalışmasından sonra her öğrenci kendi bireysel hemşirelik bakım planını yazılı olarak kaydetmiştir.

VÇ grubu olarak isimlendirilen kontrol grubu, rastgele biri 8, diğerleri 9 kişilik 4 gruba ayrılmış ve sınıf ortamında gruplar halinde oturmaları sağlanmıştır. Aynı hastaya ait veriler, araştırmacılar tarafindan sınıfta okunmuş, ardından öğrencilerin grup çalışması yapması istenmiştir. Grup çalışmasında, öğrenciler vakaya ilişkin hemşirelik tanılarını ve hemşirelik girişimlerini tartışmışlardır. Grup çalışması yaklaşık bir saat sürmüştür. Grup tartışmasından sonra her öğrenci kendi bireysel hemşirelik bakım planını yazılı olarak kaydetmiştir. SH ve VÇ grubuna ayrılan öğrenciler birbirlerinden habersiz farklı sınıflarda çalışmışlardır.

\section{VERİ TOPLAMA ARAÇLARI}


Verilerin toplanmasinda soru formu ve öğrencilerin bireysel olarak hazırladıkları bakım planları kullanılmıştır. Soru formu iki bölümden oluşmaktadır. Birinci bölümde; öğrencilerin tanıtıcı özelliklerini, eğitim yöntemine ilişkin düşünce ve görüşlerini içeren kapalı ve açık uçlu olarak hazırlanmış 10 soru vardır. İkinci bölümde ise araştırmacıların öğrenci bakım planlarını değerlendirdikleri form yer almaktadır.

Öğrencilerin hazırladığı hasta bakım planları, Gordon'un (1982) Fonksiyonel Sağlık Örüntüleri (FSÖ) modeli ve NANDA tanıları doğrultusunda değerlendirilmiştir. Araştırmacılar, bakım planlarını değerlendirmek için FSÖ modelinin 11 alanına ilişkin bir liste oluşturmuştur. $\mathrm{Bu}$ listede her bir alanla ilgili öğrencilerin sorun/tanı belirleme durumları "sorun/tan1 var", "sorun/tan1 yok" olarak kodlanmıştır. Ayrıca her öğrencinin belirlediği tanılara ve bu tanılara uygun her girişim için birer puan verilmiştir. Böylece her öğrencinin hemşirelik tanı ve girişim puanları belirlenmiştir.

\section{ÇALIŞMANIN YAPILDIĞI HEMŞİRELIKK PROGRAMININ ÖZELLIKKLERİ}

Hemşirelik Bölümü, 1997 yılında kurulmuştur. 2011- 2012 eğitim öğretim yılında; biri doçent, biri yardımcı doçent olmak üzere 2 öğretim üyesi, 6 öğretim görevlisi; 1 araştırma görevlisi olmak üzere toplam 9 öğretim elemanı vardır. Cerrahi Hastalıkları Hemşireliği Dersi ise biri öğretim üyesi ve biri araştırma görevlisi olmak üzere iki öğretim elemanı tarafindan yürütülmüştür. Ders, 6 saati teorik 18 saati klinik uygulama olmak üzere toplam 24 saattir. Dersin teorik kısmı öğretim üyesi tarafından, klinik uygulama bölümü ise iki öğretim elemanı ve bir klinik hemşiresi tarafindan yürütülmüştür. Hemşirelik bölümüne ait toplam 4 derslik ve 1 uygulama laboratuvarı vardır.
Çalışmadan elde edilen veriler hem nitel hem de nicel olarak değerlendirilmiştir. Nicel verilerin değerlendirilmesinde SPPS (Statistical Package for Social Science) 15.0 paket programı kullanılmıştır. Öğrencilerin eğitim yönteminin öğrenmeye, bakımı ve girişimleri planlamaya katkısını algılamaları 100 puan üzerinden hesaplanmıştır. Veriler yüzdelik, bağımsız gruplarda $t$ testi ile değerlendirilmiştir. Sonuçlar p değeri 0,05 altında ise anlamlı kabul edilmiştir.

Nitel verilerin değerlendirilmesinde ise açık uçlu sorular araştırmacılar tarafından oluşturulan temalara göre alt gruplara ayrılmıştır. Öğrencilerin yanıtları hem sayısal olarak hem de temalara göre değerlendirilmiştir.

\section{ARAȘTIRMANIN ETİK YÖNÜ}

Araştırmanın yapılması için ilgili kurumdan yazılı izin, Gaziosmanpaşa Üniversitesi Tip Fakültesi Etik Kurulu'ndan onay (say1:12-BADK 024, tarih:18.03.2012) alınmıştır. Araştırmalarda insan olgusunun kullanımı bireysel hakların korunmasını gerektirdiğinden, "bilgilendirilmiş onam" koşulu bir etik ilke olarak yerine getirilmiştir.

\section{BULGULAR}

Çalışmaya katılan öğrencilerin yaş ortalamaları, SH grubunda $20.51 \pm 1.142$, VÇ grubunda ise $20.88 \pm 1.51$ olarak belirlenmiştir. Çalışma grupları yaş, medeni durum, mezun olunan lise yönünden karşılaştırıldığında gruplar arasında istatistiksel olarak fark bulunmamıştır (p>0.05) (Tablo1).

Tablo 1: Öğrencilerin tantıcı özelliklerinin
dağılımı

\section{Verilerin Değerlendirilmesi}


DOI: $10.16899 /$ ctd.83205

\begin{tabular}{|l|l|l|l|l|}
\hline \multirow{2}{*}{ Özellikler } & \multicolumn{2}{|l|}{$\begin{array}{l}\text { Simüle } \\
\text { Grubu }\end{array}$} & \multicolumn{2}{l|}{$\begin{array}{l}\text { Vaka } \\
\text { Grubu }\end{array}$} \\
\cline { 2 - 5 } & Sayı & $\%$ & Sayı & $\%$ \\
\hline $\begin{array}{l}\text { Medeni Durum } \\
\text { Bekar }\end{array}$ & 35 & 100.0 & 35 & 100.0 \\
\hline $\begin{array}{l}\text { Cinsiyet } \\
\text { Kadın }\end{array}$ & 28 & 80.0 & 27 & 77.1 \\
Erkek & 7 & 20.0 & 8 & 22.9 \\
\hline $\begin{array}{l}\text { Mezun olunan } \\
\text { lise }\end{array}$ & & & & \\
Lise & 26 & 74.5 & 18 & 51.4 \\
Meslek lisesi & 7 & 20.0 & 14 & 40.0 \\
Anadalu/Fen & 2 & 5.7 & 2 & 5.7 \\
lisesi & 0 & 0.0 & 1 & 2.9 \\
Ağlik meslek & & & & \\
lisesi & & & & \\
\hline \multicolumn{2}{|l}{ Öğg. } \\
\hline
\end{tabular}

Öğrencilerin eğitim yönteminin

öğrenmeye, bakımı ve girişimleri planlamaya katkısını algılama ortalamaları 100 puan üzerinden SH grubunda 89.7, VÇ grubunda ise 80.57 'dir ve aradaki farkın istatistiksel olarak önemli olduğu saptanmıştır $(p<0.05)$. Eğitim yönteminin hemşirelik bakımını ve girişimini planlamaya katkısı yönünden arada istatistiksel olarak fark bulunmamıştır (Tablo 2).

Tablo 2: Öğrencilerin eğitim yönteminin öğrenmeye, bakımı ve girişimleri planlamaya katkısını algılama puan ortalamaları karşılaştırılması

\begin{tabular}{|c|c|c|c|}
\hline Sonuçlar & $\begin{array}{l}\text { Simüle } \\
\text { Hasta } \\
\text { Grubu } \\
\sigma \pm \text { Ss }\end{array}$ & $\begin{array}{l}\text { Vaka } \\
\text { Çalışması } \\
\text { Grubu } \\
\sigma \pm \text { Ss }\end{array}$ & $\begin{array}{l}\text { Değerlendirm } \\
\text { e }\end{array}$ \\
\hline $\begin{array}{l}\text { Öğrenmey } \\
\text { e katkısı }\end{array}$ & $\begin{array}{l}89.71 \pm 12.7 \\
1\end{array}$ & $80.57 \pm 12.11$ & $\begin{array}{l}\mathrm{p}: 0.003 \\
\mathrm{t}: 3.080\end{array}$ \\
\hline $\begin{array}{l}\text { Hemşireli } \\
\text { k bakımını } \\
\text { planlamay } \\
\text { a katkısı }\end{array}$ & $\begin{array}{l}80.00 \pm 11.4 \\
2\end{array}$ & $\begin{array}{l}82.281 \pm 12.3 \\
8\end{array}$ & $\begin{array}{l}\mathrm{p}: 0.197 \\
\mathrm{t}: 1.304\end{array}$ \\
\hline $\begin{array}{l}\text { Beceriye } \\
\text { planlamay } \\
\text { a katkısı }\end{array}$ & $\begin{array}{l}80.85 \pm 14.0 \\
1\end{array}$ & $76.00 \pm 12.64$ & $\begin{array}{l}\mathrm{p}: 0.133 \\
\mathrm{t}: 1.522\end{array}$ \\
\hline
\end{tabular}

Öğrencilerin hemşirelik tanı puan ortalamaları SH grubunda $18.22 \pm 3.04$, VÇ grubunda $13.50 \pm 2.91$, hemşirelik girişim puan ortalamaları SH grubunda $66.65 \pm 16.05$, VÇ grubunda ise $51.65 \pm 14.27$ olarak belirlenmiştir. Her iki grup arasındaki farkın istatistiksel olarak önemli olduğu bulunmuştur $(\mathrm{p}<0.05)$ (Tablo 3$)$.

Tablo 3: Öğrencilerin tanı ve girişim puan ortalamalarının karşılaştırılması

\begin{tabular}{|l|l|l|l|}
\hline $\begin{array}{l}\text { Sonuçla } \\
\text { r }\end{array}$ & $\begin{array}{l}\text { Simüle } \\
\text { Hasta } \\
\text { Grubu } \\
\square \pm \text { Ss }\end{array}$ & $\begin{array}{l}\text { Vaka } \\
\text { Çalışması } \\
\text { Grubu } \\
\square \pm \text { Ss }\end{array}$ & $\begin{array}{l}\text { Değerlendir } \\
\text { me }\end{array}$ \\
\hline $\begin{array}{l}\text { Tanı } \\
\text { puanı }\end{array}$ & $18.22 \pm 3.04$ & $15.50 \pm 2.91$ & $\begin{array}{l}\text { p: } 0.001 \\
\text { t: } 6.580\end{array}$ \\
\hline $\begin{array}{l}\text { Girişim } \\
\text { puanı }\end{array}$ & $\begin{array}{l}66.65 \pm 16.0 \\
5\end{array}$ & $\begin{array}{l}51.65 \pm 14.2 \\
7\end{array}$ & $\begin{array}{l}\text { p: } 0.001 \\
\text { t: } 4.130\end{array}$ \\
\hline
\end{tabular}

SH ile çalışan öğrencilere düşünceleri sorulduğunda hepsi bu eğitimin kendileri için yararlı olduğunu ifade etmişlerdir. Öğrencilerin konu ile ilgili görüşleri; "Etkili öğrenmeyi sağladı (10)", "Gerçek hastayla çalışma şansı sağladı (10)", "Hastanın öncelikli bakım gereksinimlerini fark ettim (6)", "Hastayla iletişimi öğrendim (5)", "Hastayı bütüncül ele almayı öğrendim (5),” şeklinde gruplandırılmıştır (Tablo 4).

Tablo 5 'te öğrencilerin vaka çalışmasına ilişkin görüşleri yer almaktadır. Öğrencilerin konu ile ilgili görüşleri; "Etkili öğrenmeyi sağladı (9)", "Hasta bakımını planlamayı öğrendim (8)", "Eksiklerimi fark etmemi sağlad1 (7)", "Hastayı bütüncül ele almayı öğrendim (5)", “Kliniğe hazırladı (5)”, şeklinde gruplandırılmıştır (Tablo 5).

\section{TARTIŞMA}

Simülasyon kullanımı, öğrencilerin konforlu ve destekleyici bir ortamda yeni edindikleri beceriyi güven içinde yapmalarına destek vermesi açısından önemlidir (19). Bunun yanı sıra öğrencilerin anksiyete, hata yapma korkusu, güven eksikliği gibi duygular yaşamadan deneyim kazanmasına izin vermektedir (2,7). $\mathrm{Bu}$ çalışmada örneklem sayısının küçük olmasına rağmen elde edilen sonuçlar geleneksel eğitim yöntemlerine ek olarak yenilikçi uygulamaların kullanımına ilişkin ön bilgiler sağlamaktadır.

Tablo 4: Simule hastayla çalışan öğrencilerin eğitim yöntemi hakkındaki görüşlerinin dağılımı

\begin{tabular}{|l|l} 
Temalar & Örnek ifadeler
\end{tabular}


DOI: $10.16899 /$ ctd. 83205

\begin{tabular}{|c|c|}
\hline $\begin{array}{l}\text { Etkili öğrenmeyi sağladı } \\
\text { (10). }\end{array}$ & $\begin{array}{l}\text { - Öğrenmenin etkili ve kalıcı } \\
\text { olmasını sağladı. } \\
\text { - Bilgiyi yorumlamamı } \\
\text { kolaylaştırdı. } \\
\text { - Derste anlatılanların havada } \\
\text { kalmasını önlüyor, etkili } \\
\text { öğrenmeyi sağlıyor. } \\
\text { - Etkin öğrenmemi sağladı. }\end{array}$ \\
\hline $\begin{array}{l}\text { Gerçek hastayla çalışma } \\
\text { şansı sağladı (10). }\end{array}$ & $\begin{array}{l}\text { - Hastane ortamına gitmeden } \\
\text { oradaymış gibi hissetmemi } \\
\text { sağladı. } \\
\text { - Gerçek hasta sandım, klinik } \\
\text { öncesi korkumu azalttı. } \\
\text { - Gerçek hastayla görüşme } \\
\text { yapıldığını düşündüm. } \\
\text { - Hastalıklarla ilgili hastanın } \\
\text { yaşadıklarını daha iyi } \\
\text { anladım. }\end{array}$ \\
\hline $\begin{array}{l}\text { Hastanın öncelikli bakım } \\
\text { gereksinimlerini fark ettim } \\
\text { (6). }\end{array}$ & $\begin{array}{l}\text { - Hastanın öncelikli bakım } \\
\text { gereksinimlerini fark etmemi } \\
\text { sağladı. } \\
\text { - Hemşirelik verilerini } \\
\text { toplamayı ve tanısını } \\
\text { koymamı kolaylaştırdı. } \\
\text { - Hasta bakım planını daha } \\
\text { etkili yapmayı öğrendim. }\end{array}$ \\
\hline $\begin{array}{ll}\text { Hastayla } & \text { iletişimi } \\
\text { öğrendim (5). } & \end{array}$ & $\begin{array}{l}\text { - Hastayla nasıl iletişim } \\
\text { kurulacağını görme şansım } \\
\text { oldu. } \\
\text { - Veri toplarken hastayla } \\
\text { iletişim kurmayı ögrendim. } \\
\text { - Hastayla iletişimi } \\
\text { geliştirmesi açısından etkin } \\
\text { olduğunu düşünüyorum. }\end{array}$ \\
\hline $\begin{array}{lr}\text { Hastayı bütüncül } & \text { ele } \\
\text { almayı öğrendim }(5) . & \end{array}$ & $\begin{array}{l}\text { - Hastayı bütüncül ele } \\
\text { almamı kolaylaştırdı. } \\
\text { - Hastayı her yönde daha iyi } \\
\text { anlamamı sağladı. }\end{array}$ \\
\hline
\end{tabular}

Çalışmada, öğrencilerin hemşirelik bakım planı oluşturma becerilerini yeterli yetersiz olarak değerlendirmekten ziyade hemşirelik bakımını planlayabilme becerilerini geliştirmeleri hedeflenmiştir. Çalışmada, öğrencilerin eğitim yönteminin öğrenmeye, bakımı ve girişimleri planlamaya katkısını algılama ortalamaları SH grubunda 89.7, VÇ grubunda ise 80.57 'dir ve aradaki fark istatistiksel olarak önemlidir $(\mathrm{p}<0.05)$.

Tablo 5: Vaka çalışması yapan öğrencilerin eğitim yöntemi hakkındaki görüşlerinin dağglımı

\begin{tabular}{|l|l|}
\hline Temalar & Örnek ifadeler \\
\hline
\end{tabular}

\begin{tabular}{|c|c|}
\hline $\begin{array}{l}\text { Etkili öğrenm } \\
\text { sağladı (9). }\end{array}$ & $\begin{array}{l}\text { - Vaka çalı̧̧ması öğrenmenin } \\
\text { etkili ve kalıcı olmasını } \\
\text { sağlıyor. } \\
\text { - Karşılıkı bilgi alışverişi ile } \\
\text { öğrenme kolaylaştı } \\
\text { - Derse olan ilgimi artırdı. }\end{array}$ \\
\hline $\begin{array}{l}\text { Hasta bakımını } \\
\text { planlamayı } \\
\text { öğrendim (8). }\end{array}$ & $\begin{array}{l}\text { - Hasta bakım planını yapma } \\
\text { becerim arttı. } \\
\text { - Hastaya verilecek bakımı } \\
\text { planlamama yardımcı oldu. }\end{array}$ \\
\hline $\begin{array}{l}\text { Eksiklerimi fark } \\
\text { etmemi sağladı(7). }\end{array}$ & $\begin{array}{ll}\text { - Eksik olduğum } & \text { yönlerimi } \\
\text { fark ettim. } & \\
\text { - } \quad \text { Kaçırdığım } & \text { noktaları } \\
\text { görmemi sağladı. } & \\
-\quad \text { Bildiklerimin } & \text { farkına } \\
\text { vardım. } & \end{array}$ \\
\hline $\begin{array}{l}\text { Hastayı bütüncül ele } \\
\text { almayı öğrendim (5). }\end{array}$ & $\begin{array}{l}\text { - } \quad \text { Kapsamlı düşünmeyi } \\
\text { sağladı. } \\
-\quad \text { Hastayı her } \\
\text { değerlendirdik, } \\
\text { yaklaşmayı öğrendidan. }\end{array}$ \\
\hline $\begin{array}{l}\text { Klinik uygulama } \\
\text { hazırladı (5). }\end{array}$ & $\begin{array}{l}\text { - Klinik uygulamasına ön } \\
\text { hazırlı oldu. } \\
\text { - Nitelikli bakım vermemi } \\
\text { kolaylaştırd. Kliniğe ön } \\
\text { hazırlı oldu. }\end{array}$ \\
\hline
\end{tabular}

Hemşirelik eğitiminde simulasyon kullanımı öğrenciye interaktif öğrenme ortamı sağlamaktadır. Öğrenciler sadece karmaşık hasta senaryosunu öğrenmekle kalmaz, aynı zamanda gerçek duruma uygun uygulama yapma olanağ 1 da bulmaktadır (2). Nitekim Becker ve arkadaşlarının (20) simüle hasta ile geleneksel yöntemle karşılaştırdıkları araştırmalarında; öğrenciler simüle hastayla çalışmanın öğrenmeye katkısını ortalama 3.28 (0: etkisiz, 4: çok fazla etkili) ile fazla etkili olarak değerlendirmişlerdir (20). Ayrıca May, Park ve Lee (19) eğitim ve öğretimde simüle hasta kullanımına ilişkin 10 yıllık literatür taraması yapmışlardır. Yazarlar literatür taramasında; simüle hastayla çalışmanın, öğrenenlerin öğrenme deneyimine olumlu yönde katk1 sağladığını, sadece bir çalışmada negatif yönde etkisi olduğunu belirlemişleridir. Benzer şekilde Myung ve ark. (14) da öğrencilerin \%80'nin SH ile çalışmaktan memnun kaldığını belirlemiştir. 


\section{DOI: $10.16899 /$ ctd. 83205}

$\mathrm{Bu}$ bulgular çalışma sonuçlarımızı destekler niteliktedir.

Çalışmamızda hem VÇ hem de SH grubundaki öğrencilerin ifadelerine göre; öğrenme yönteminin hemşirelik bakımını ve girişimlerini planlamaya katkısı her iki yöntemde de benzer orandadır ve iki grup arasında istatistiksel olarak fark bulunmamıştır. Ancak öğrencilerin hemşirelik tanı belirleme ortalama puanları ile hemşirelik girişim puan ortalamaları arasındaki farkın istatistiksel olarak önemli olduğu bulunmuştur $(\mathrm{p}<0.05)$. Buna göre SH ile çalışmanın, VÇ'ye göre öğrencilerin hemşirelik tanısını belirlemeye ve girişimleri planlamaya daha fazla katkı sağladığı sonucuna ulaşılabilir. Yoo ve Yoo (15)'nun yaptıkları araştırmada simüle hasta ile çalışan grubun hemşirelik sorunlarını ve vakaya uygun hemşirelik bakımını belirlemeye ilişkin ortalama puanlarının, klasik eğitim grubuna göre daha yüksek olduğu ve aradaki farkın istatistiksel olarak önemli olduğu bulunmuştur. Çalışmamızın bulguları Yoo ve Yoo(15)'nun bulgularıyla paralellik göstermektedir.

Çalışmaya katılan öğrenciler hem SH hem de VÇ yöntemlerine ilişkin olumlu görüş bildirmişlerdir. Her iki çalışma yönteminin "Etkili öğrenmeyi" ve "Hastayı bütüncül ele almayı öğrenmeyi” sağladığı belirlenmiştir. Öğrenci ifadeleri incelendiğinde "Etkili öğrenmeyi sağladı" teması altında SH grubu; "Öğrenmenin etkili ve kalıcı olmasını sağladı", "Bilgiyi yorumlamamı kolaylaştırdı", "Derste anlatılanların havada kalmasını önlüyor, etkili öğrenmeyi sağlıyor", "Etkin öğrenmemi sağladı", VÇ grubu ise "Vaka çalışması öğrenmenin etkili ve kalıcı olmasını sağlıyor”, "Karşıllıkı bilgi alışverişi ile öğrenme kolaylaştı" ifadelerini kullanmıştır. "Hastayı bütüncül ele almayı öğrenme" teması altında SH grubu; "Hastayı bütüncül ele almamı kolaylaştırdı", "Hastayı her yönde daha iyi anlamamı sağladı" ifadeleri kullanırken VÇ grubunda ise "Kapsamlı düşünmeyi sağladı", "Hastayı her açıdan değerlendirdik, holistik yaklaşmayı öğrendim" ifadeleri kullanılmıştır. Hem VÇ, hem de SH çalışmasının geleneksel eğitim yöntemi olan anlatım yönteminden farkl1 olması nedeniyle öğrenciler her iki yönteme ilişkin olumlu geribildirim vermiş olabilirler.

Robinson-Smith ve ark. (16) SH ile çalışmayı öğretici, eğlenceli ve etkin olarak ifade ederken, Ebbert ve Connors(13) de gerçekçi ve yararlı olarak ifade etmiştir. Simüle hasta, gerçek hastanın duygusal boyutunu gerçekçi bir şekilde yansıtarak, simulatörlerin eksikliğini gideren bir öğretim yöntemidir (16). Öğrencileri klinik ortamlara hazırlamak için oluşturulan senaryo temelli simüle hasta çalışmaları, öğrenciler için iyi bir öğrenme deneyimi sağlamaktadır (18). Simüle hasta kullanımıyla öğrenci hemşireler verdikleri bakımın etkilerini hasta üzerinde gözlemleyebilmektedir (16). Aslında, hemşirelik öğrencilerinin özel ihtiyaçlarını karşılamak için hazırlanmış simüle hasta vakaları, gerçek klinik ortam kadar etkili olabilmektedir (15). Nitekim çalışmamızda öğrenciler SH ile çalışmanın "Gerçek hastayla çalışma şansı sağlaması" teması altında "Hastane ortamına gitmeden oradaymış gibi hissetmemi sağladı", "Gerçek hasta sandım, klinik öncesi korkumu azalttı", "Gerçek hastayla görüşme yapıldığını düşündüm", "Hastalıklarla ilgili hastanın yaşadıklarını daha iyi anladım" ifadelerini kullanmışlardır.

\section{ARAȘTIRMANIN SINIRLILIKLARI}

$\mathrm{Bu}$ çalışmasının bir takım sınırlıkları vardır. Bunlardan ilki hem sinıf ortamının kalabalık olması hem de öğrenci görüşmelerinin video ile kaydedilip, sonradan öğrenciye geri bildirim verilecek fiziki ortamın olmamas1 nedeniyle, öğrenciler SH ile birebir görüşme yapamamıştır. Ancak öğrenciler hasta-hemşire görüşmesine ilişkin rol modelini izleme olanağ bulmuşlardır.

İkinci sinırlılık ise simüle hasta senaryosunu oluşturulması ve kaynak sağlama ile ilgilidir. Hasta senaryosu oluşturmak zaman ve maddi kaynaklar yönünden yoğun emek gerektirmektedir. SH rolünü oynayacak uygun bireyin bulunması, bu bireyin eğitimi ve ücretini 
ödemek için kaynak bulma araştırmacılar için sıkıntılı ve güç olmuştur. $\mathrm{Bu}$ çalışmada ön hazırlık çalışması yaklaşık bir ay, SH için tiyatro sanatçısının eğitimi ve hazırlanması15 gün sürmüştür. $\mathrm{SH}$ rolünü oynayan tiyatro sanatçısının ücreti için kaynak bulunamamıştır. $\mathrm{Bu}$ sinırlılıklara rağmen araştırmacılar bu çalışmayı, öğrencinin kliniğe gitmeden önce canlı hasta modeliyle karşılaşma şansı yakalamasını ve sınırlı kaynaklara sahip ortamlarda da geleneksel öğretim yöntemlerinin dışında farklı öğretim yöntemlerinin uygulanabileceğini göstermek amaciyla yapmışlardır.

Araştırma kapsamına alınan örneklem sayısının az olması ve çalışmanın bir hemşirelik bölümünde ve 2 . sınıf öğrencilerine uygulanmas1 araştırmanın diğer sınırlılığıdır. Çalışma ve kontrol grubunun aynı sınıftan alınması da çalışmanın bir sınırlığıdır. Ancak çalışma ve kontrol gruplarının farklı ortamlarda birbirinden habersiz çalışmaları, grupların birbirlerini etkilemelerinin kontrol altına alınması ise çalışmanın güçlü yanını oluşturmaktadır.

\section{SONUÇ}

Öğrenciler hem SH hem de VÇ yöntemlerine ilişkin olumlu görüş bildirmişlerdir. Ancak öğrenciler, eğitim yöntemlerinin öğrenmeye, bakımı ve girişimleri planlamaya katkısını SH grubu daha fazla katkı verdi olarak algılamıştır ve aradaki fark istatistiksel olarak önemli bulunmuştur. Ancak SH grubu VÇ grubundan farklı olarak eğitim yönteminin yararları hakkında "Gerçek hastayla çalışma şansı sağlaması", "Hastanın öncelikli bakım gereksinimlerini fark etmesi", "Hastayla iletişimi öğrenmeyi” sağladığını ifade etmişlerdir. Dolayısıyla SH kullanımının öğrencilerin gerçeğe en yakın tıbbi durumları, klinik problemleri değerlendirilmesine ve hemşirelik bakımının planlanmasına katkı sağladığı düşünülmektedir. Hemşirelik literatüründe bu tür çalışmaların yer almasının hemşirelik eğitiminin gelişmesi ve eğitim yöntemlerinin zenginliği açısından da önemli olduğu düşünülmektedir. Nitekim son y1llarda hasta güvenliği açısından ve çeşitli uygulamaların yapılması amaciyla eğitimde simülasyon kullanımı giderek artmaktadır. Gelecekte de artan yoğunlukta kullanılması beklenilmektedir.

\section{KAYNAKLAR}

1. Ryan CA, Walshe N, Gaffney $\mathrm{R}$ et al. Usingstandardized patients to assess communication skills in medical and nursing students. BMC Med Educ 2010;10 (24):1-8.

2. Rhodes LM Curran C. Use of the human patient simulator to teach clinical judgment skills in a baccalaureate nursing program. Computer, Informatics. Nursing 2005;23(5): 256-262.

3. Flynn K. The use of standardized patients to minimize anxiety in undergraduate nursing students in the clinical setting. Master of arts in nursing theses. 2012;58.

4. Rauen CA. Simulation As A Teaching strategy for nursing education and orientation in cardiac surgery. Crit Care Nurs Quarterly 2004;24(3):46-51.

5. Metcalfe SE, Hall VP, Carpenter A. Promoting coolaboration in nursing education: The development of regional simuulation laboratory. J Prof. Nurse 2007;23:180-183.

6. Gaba D M. The future vision of simulation in health care, Quality\&Safety Health Care 2004;13(1):2-10.

7. Alinier G. A typology of educationally focused medical simulation tools. Med Teach 2007;29:e243-e250

8. Dikici MF, Yarış F. Ondokuz Mayıs Üniversitesi Tıp Fakültesi klinik beceri eğitiminde standardize ve simüle hasta programı. J Med Sci 2007;27; 738-743.

9. Levine A, Swartz M. Standardized patients: The "other" simulation. J Crit Care 2008;23: 179-184

10. Good, ML. Patient simulation for training basic and advanced clinical skills. Med Educ 2003;37(1):14-21.

11. Overstreet N. Technology in education of nursing students. Nurse Clin. N Am 2008;43:593-603.

12. Tiffen J, Corbridge S, Shen BC et al. Patient simulator for teaching heart and lung assessment skills to advanced practice nursing students. Clinic Simul Nurs 2011;7:e91-e97.

13. Ebbert DH, Connors H. Standardized patient experiences: Evaluation of Clinical Performance and Nurse Practitioner Student Satisfaction. Nurs Educ Perspect 2004;25(1):12-15.

14. Myung SY, Kang SH, Kim YS et al. The use of standardized patients to teach medical students clinical skills in ambulatory care settings. Med Teach 2010; 32: e467-e470

15. Yoo MS, Yoo Y. The effectiveness of standardized patients as a teaching method for nursing Fundamentals. J Nurs Educ 2003;42(10):444-448. 
Çağdaş Tıp Dergisi 2015;5(1): 36-44

Karadağ ve ark.

DOI: $10.16899 /$ ctd. 83205

16. Robinson-Smith G, Bradley PK, Meakim C. Evaluating the use of standardized patients in undergraduate psychiatric nursing experiences November. Clinic Simul Nurs 2009;5 (6):e203-e211.

17. May W, Park JH, Lee J. A ten year review of the literature on the use of standardize patients in teaching and learning : 1996-2005. Med Teach 2009;31:487-492.

18. Lucthar- Flude M, Wilson- Keates B, Larocque M. Evaluating high-fidelity human simulators and standardized patients in an undergraduate nursing health assessment course. Nurse Educ Today 2012;32(4):448-52.

19. Bremner MN, Aduddell K, Bennett DN et al. The use of human patient simulators best practices with novice nursing students. Nurse Educ2006;31(4):170-174.

20. Becker KL, Rose LE, Berg JB et al. The teaching effectiveness of standardized patients, J Nurs Educ 2006;45(4):103-111. 